produserer serotonin blir aktive. Eller ved presentasjon av teorier om drøm («Winsons teori») som undertegnede, som har arbeidet i dette feltet i ti år, aldri har hørt om tidligere. Dette svekker troverdigheten. Jeg kunne tenke meg en betydelig bedre lærebok om søvnlidelser enn dette.

Roar Fosse

Psykisk helse

Sykehuset Asker og Bærum

\section{Hvilken terapi?}

Arnet E.

Terapi

Hva passer for meg? 212 s. Oslo: Gyldendal

Akademisk, 2009. Pris NOK 295

ISBN 978-82-05-38898-7

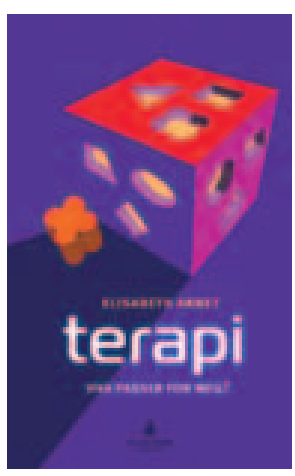

Forfatter Elisabeth

Arnet henvender

seg til alle som

ønsker å gå i terapi

og vil vite mer om

hva som karakteri-

serer ulike terapi-

former. I tillegg får

vi en kort innføring

i det teoretiske

grunnlaget for hver

av terapiformene

som presenteres.

Forfatteren starter med å alminneliggjøre behovet for å gå i terapi, for så å gi en generell innføring i hva det innebærer. Ni ulike terapiformer blir presentert, de fleste i eget kapittel. På slutten av hvert kapittel gir forfatteren eksempel på hvordan samtalen vil være innenfor den terapi som presenteres. Selvhjelpsgrupper blir også kortfattet omtalt. Til slutt gir forfatteren stemme til mennesker som har vært i terapi og som forteller hvordan de opplevde det å gå $\mathrm{i}$ terapi og hvilket utbytte de har hatt. Til slutt i boken er det oversikt over en del nettressurser, med adresser til ulike terapiinstitutter og foreninger.

De ulike terapiformene presenteres ryddig og kortfattet, uten bruk av mange vanskelige ord og faglig sjargong. Forfatteren starter med å omtale hva terapi hos psykolog er, for så å beskrive psykoanalyse. Men jeg savner en generell innføring i hva psykoterapi er. Det er også flere alminnelige terapiformer og -retninger som er i bruk innen spesialisthelsetjenesten som ikke omtales, som f.eks. gruppeterapi og mentalisering. Det brukes derimot mye plass på marginale terapiformer som «innerlife»-terapi og rosenterapi. Den største mangelen er at forfatteren ikke går mer i dybden og gir plass til hvordan en som går i terapi skal kunne vurdere om den hjelper eller ikke. Hun sier flere ganger at kjemien må stemme - gjør den ikke det, kan man skifte terapeut. Men er det et riktig faglig råd - og realistisk å få til? Psykiatere som terapeuter blir nesten ikke omtalt.

Er dette en bok jeg kan anbefale? Deler av den er lettfattelig og informativ, og det er helt sikkert et behov for denne type opplysning. I tittelen angis det at boken skal gi generell informasjon om hva terapi er, og det gjør den dessverre bare delvis. Boken preges i for stor grad av forfatterens syn på hva terapi er. Boken henvender seg også i for stor grad til mennesker med mindre alvorlige psykiske plager og berører ikke hva terapi er for mennesker med langvarige alvorlige psykiske plager, som alvorlig depresjon og psykoser. Konklusjonen er at boken har nyttig informasjon, men er for snever i omtale av hva terapi er.

\section{Ann Færden}

Avdeling for forskning og undervisning

Oslo universitetssykehus, Ullevål

\section{En samtale om kropp og smerte?}

Pihl M.

Det andre muskellaget

86 s, ill. Oslo: Kolofon forlag, 2009. Pris NOK 235 ISBN 978-82-300-0509-5

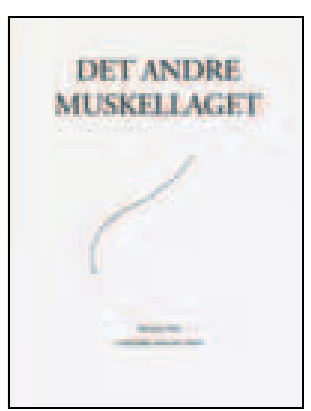

Forfatteren Merete Pihl er psykomotorisk fysioterapeut med mange års erfaring som terapeut og lærer. Hun har valgt å skrive om denne erfaringen med sin egen kropp og sine egne tap som utgangspunkt. Refleksjonene over bevegelser og smerter, som hun lar leseren tar del i, er en førstepersons fortelling til en annen person, en anonym venn, som responderer. Leseren blir slik en tredjeperson - om han eller hun vil - som blir betrodd intim viten om forfatteren, dog på en måte som virker kryptert eller kodet. Slik forblir personen som snakker skjult som bak et slør, en som angir å ville vise seg, men likevel ikke gjør det.

Denne forunderlige formen for utydelighet blir understreket av at vennens responser ikke står i noe åpenbart logisk meningsforhold til forfatterens forutgående beskrivelser eller betroelser. Og siden leseren må anta at vennen svarer eller kommenterer ut fra en stor fortrolighet med forfatteren, holder de to samtalende personene leseren $\mathrm{i}$ en viss forstand utenfor.

Kan det tenkes at forfatteren både vil og ikke vil vise seg? Og hva vil hun oppnå ved ikke å oppgi sin ambivalens? Vil hun skape forvirring? Vil hun vekke skjerpet oppmerksomhet? Hun omtaler tidlig en liten jente i seg selv, den voksne kvinnen, en jente som ikke ble den hun var ment å være. Leseren ser kvinnen som invalidiseres av smerte og utmattelse, som rammes av brystkreft og cellegift. Og i et lite glimt ser leseren en liten jente som ble stående igjen da familien reiste fra henne i en grønn bil. Hun ble - for veldig lenge siden - etterlatt på et rekonvalesenthjem for barn «for å få i seg nok proteiner»».

Var det da pusten stoppet og musklene utenpå og inne i kroppen mistet sitt selvfølgelige, trygge og vitalitetsbevarende samvirke? Er det dette bruddet forfatteren prøver å hele i sine øvelser på gulvet og med sin egen terapeut i sine forsøk på å samstemme musklene igjen? Er det betydningen av et biografisk brudd, ment for å bevare hennes helse, som fortelleren vil formidle til sine kolleger i helsefagene? Vil hun, selv en profesjonell hjelper, bruke seg selv for å gjøre andre hjelpere oppmerksomme på hvor vanskelig det er for fortvilte mennesker å «løfte på sløret» som skjuler kildene til deres fortvilelse, smerte og angst?

\section{Anna Luise Kirkengen}

Senter for helsefremmende arbeid Akershus universitetssykehus

\section{En ullen sak}

\section{Porthun J.}

Osteopati

For spedbarn, barn og voksne. $68 \mathrm{~s}$, ill.

Bøverbu: Ondefo forlag, 2008. Pris NOK 129 ISBN 978-82-8190045-5

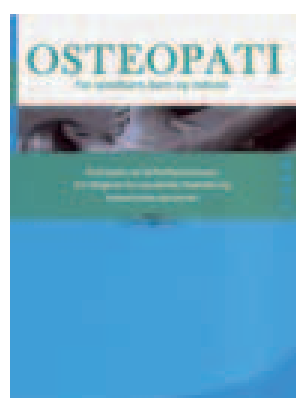

Forfatteren henvender seg i første omgang til pasienter, foreldre og potensielle pasienter og forsøker å gi en oversikt over osteopati som behandlingsform. Osteopati fremheves som et helhet-

lig, svært omfangsrikt konsept innenfor det helsefaglige området. De enkelte sykdommer eller plager er ikke hovedsaken, det er individet i sin helhet som står i sentrum. Osteopati retter seg mot hele mennesket. En osteopatisk terapeut søker etter årsaken til plager og sykdommer.

Undersøkelse og behandling foregår overveiende med hendene. Hemmeligheten ligger, ifølge forfatteren, i langvaring, intens trening av følesansene - «slik blir hendene sensible instrumenter som kan oppdage små forandringer og forstyrrelser i kroppens vevsstrukturer». Osteopaten stoler på sensorapparatet $\mathrm{i}$ hendene sine. I Norden er det stort sett fysioterapeuter som tar utdanning i osteopati. 
Her forsøker man ved hjelp av tekst og bilder å fremstille de forskjellige osteopatiske teknikker som terapeuten anvender. Tekstenes sparsomme utforming gjør det vanskelig å få noe ut av dette. Forfatteren kommer også med en lang liste om hva osteopati kan brukes til. Den inneholder det meste av det godtfolk plages av for tiden alt fra kronisk utmattelse til problemer relatert til kjeveledd og tenner. Barn og spedbarn anses også som en viktig kundegruppe. «Hvis ikke barn skriker høyt eller skriker med en gang etter en fødsel anbefales en osteopatisk konsultasjon i løpet av de første månedene.» De siste fem sidene omhandler heste- og hundeosteopati, også dette er skrevet i kjekt-å-vite-stil.

Etter å ha vært igjennom teksten et par ganger anser jeg Osteopati som lite hensiktsmessig til bruk for pasienter. Kritisk gjennomgang reiser flere problemstillinger enn det den gir svar på, og den kan således ikke anbefales for noen målgruppe.

\section{Aage Bjertnæs}

Risvollan legesenter

Trondheim

\section{Felles skjebne, men for dårlig trøst}

Thorsen K, Myrvang VH.

Livsløp og hverdagsliv med utviklingshemning

Livsberetninger til personer med

utviklingshemning og deres eldre foreldre.

304 s. Tønsberg: Forlaget Aldring og helse,

2008. Pris NOK 290

ISBN 978-82-8061-102-4

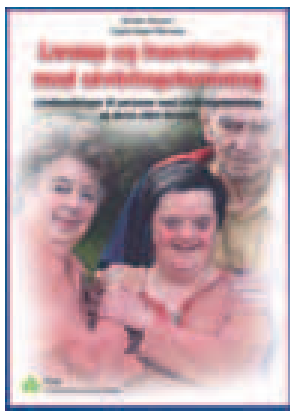

Denne utgivelsen bygger på intervjuer med 20 eldre foreldre som har hatt omsorgen for sine funksjonshemmede barn gjennom mange år, så lenge at de to generasjonene begge er kommet opp $\mathrm{i}$ årene. I tillegg er fem av de voksne barna intervjuet. Forfatterne er erfarne forskere som har arbeidet mange år med funksjonshemning og med aldring. Kirsten Thorsen er psykolog og professor II, Vigdis Hegna Myrvang er etnolog og seniorforsker.

Det er 17 kapitler fordelt på fire deler. Del 1 er den teoretiske bakgrunnen og tilnærmingen (kvalitative intervjuer). Del 2 inneholder åtte livsberetninger fra foreldre og deres barn. Del 3 er en systematisk beskrivelse av erfaringene, fordelt på de viktigste livsområdene. Del 4 er diskusjon, konklusjoner og anbefalinger. Livsløp og hverdagsliv med utviklingshemning er detaljert og grundig med over 100 noter og 17 sider med referanser til norsk og internasjonal litteratur. Dette er derfor en komplett og viktig lærebok om «det levde livet» til foreldrene og deres voksne barn. En del av barna har Downs syndrom, andre har så sammensatte og krevende funksjonshemninger at de ikke kunne intervjues.

Det kommer tydelig frem at foreldrenes omsorg har vært meget krevende, ofte så krevende at den har fylt hele livet. Belastningene har vært store, men foreldrene føler også at omsorgen har gitt dem meget, fremfor alt et nært og varmt forhold til disse barna. Barna har på sin side vært helt avhengige av foreldrenes og særlig morens utrettelige omsorg, og de har belønnet dem med stor kjærlighet. Aldringsprosessen er en utfordring for begge generasjoner, særlig for foreldrene når de passerer 70 år og merker at de orker mindre enn før. En felles bekymring har alle foreldrene: Hvordan skal det gå når vi dør?

Flere husker «gamle dager» i institusjonene, før HVPU-reformen i 1991. De føler at myndighetene har sviktet sin egen reform og dens idealer. Langt på vei er den bare blitt en boligreform. De funksjonshemmede flytter ut til egne boliger, men ofte er tjenestene og omsorgen i boligene kritikkverdige. Det er for få ansatte, mange mangler utdanning og fagkunnskaper, og - fremfor alt - er det en total mangel på kontinuitet. Derfor blir det ofte ingen tilknytning mellom beboerne og personalet. Dagsenter og arbeidstilbud fungerer bedre, men har de samme problemene. Både fagkunnskap og personlig kjennskap til beboerne mangler ofte. Foreldrene beskriver en årelang og trøstesløs kamp mot det kommunale byråkratiet, og mange gir opp. Som leser får jeg et klart inntrykk av at det er behov for et trinn 2 i HVPU-reformen. Trinn 1 var flyttingen fra institusjon til bolig, trinn 2 må bli kunnskap, ansvar, omsorg og kontinuitet i alle ledd i de kommunale tjenestene.

Boken er klart disponert og har godt språk. Dokumentasjonen er omfattende, men forfatterne understreker at dette er en kvalitativ beskrivelse av forholdene i Oslo og Bergen, ikke en representativ kvantitativ undersøkelse som dekker hele landet.

Derfor finnes det heller ingen figurer eller tabeller. Forholdene er antakelig bedre i mindre landkommuner, men problemene finnes nok overalt. Jeg har to innvendinger. Den ene er at jeg tror at man hadde tjent på en mer kortfattet fremstilling, den andre er at det mangler et sakregister. Likevel er jeg ikke i tvil om at dette er en nyttig og viktig utgivelse som bør leses av alle som arbeider i dette feltet, og fremfor alt av kommunale ledere.

\section{Peter F. Hjort}

Blommenholm

\section{Kort og nyttig om medikamentresistens ved tuberkulose}

Verdens helseorganisasjon

Anti-tuberculosis drug resistance in the world Report nr. 4. 151 s, tab, ill. Genève: WHO, 2008. Pris CHF 30

ISBN 978-92-4156361-1

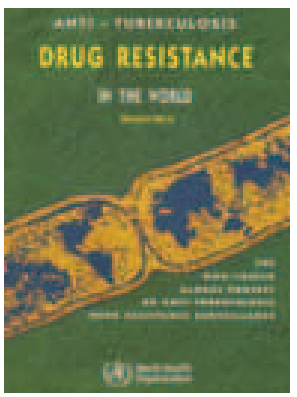

Målgruppen for denne rapporten er først og fremst personer og institusjoner som arbeider med tuberkulose, men den burde være av interesse for alle som er opptatt av globale helsespørsmål.

Den innledes med et meget velskrevet sammendrag, der de viktigste punktene oppsummeres og diskuteres. Hoveddelen består av et omfattende metodekapittel, som følges av et fyldig resultatkapittel, rikelig illustrert med tabeller og figurer. Rapporten omhandler både resistens mot enkeltmedikamenter, multiresistens (MDR) og utbredt resistens (XDR). Nye tilfeller og de som er tidligere behandlet for tuberkulose omtales hver for seg, likeledes forholdet mellom resistens og hivinfeksjon. Diskusjonskapitlet omhandler både metodologi, globale trender, forholdet mellom utbredt resistens og multiresistens, resistens ved hiv og globale estimater. Hver WHO-region diskuteres separat. I tillegg fremheves betydningen av det internasjonale nettverket av overnasjonale referanselaboratorier.

Anti-tuberculosis drug resistance in the world er velskrevet, med en behagelig layout. Den er lett å finne frem i, både pga. organiseringen av innholdet og fordi hvert hovedkapittel har en egen fargekode i margen.

Datagrunnlaget er basert på rapporter fra 114 land samt fra to administrative regioner (Special Administrative Regions, SAR) i Kina (Hongkong og Macau). Gjennomsnittlig forekomst av multiresistent tuberkulose er angitt til 5,3\%, men varierer fra $0 \%$ i enkelte vestlige land til over $35 \%$ enkelte tidligere sovjetstater. Det er enkelte land det i tidligere Sovjetunionen og noen provinser i Kina som har den høyeste forekomst av multiresistens, mens land i Vest-Europa og Afrika har den laveste.

I de fleste lavprevalensområder er det ingen økning i multiresistent tuberkulose. I de baltiske landene, som lenge har vært en bekymring, er det nedgang i antall meldte tuberkulosetilfeller og andelen tilfeller med multiresistens er stabil. I enkelte områder i Russland er det imidlertid en markant økning både i andel og absolutt antall multiresistenstilfeller, noe som er meget bekym- 